\title{
The Worship of Guardian Deities of Village Quan Nhân: The Reinvention of a Tradition
}

\author{
Hung Gia Nguyen
}

\begin{abstract}
This paper investigates the worship of village guardian deities in the lives of the villagers of Village Quan Nhân which is located in an urban area in contemporary Vietnam. In recent years, especially since the launch of the Đổ $i$ mới, Renovation, in 1986, Vietnam has experienced a revitalisation of popular religion in general and village rituals and festivals in particular after a period of suspension due to different reasons. The worship has also benefited from the reform of the cultural and religious policies of the Party-State of Vietnam in building Vietnamese culture. The paper also attempts to argue that the worship of village guardian deities of Village Quan Nhân has revived as the continuing of a tradition. The potent symbol of the guardian deities, to a certain extent, meets villagers' spiritual and recreational needs in once promising favourable weather for ample crops and now dealing with social insecurity and market uncertainty. The revival of the worship reflects how modernity accommodates tradition in contemporary Vietnam as festivals strengthen community spirit and morality.
\end{abstract}

Index Terms—Festival, ritual, tradition, village.

\section{INTRODUCTION}

During the French colonial time, Quan Nhân was one of the traditional villages of Nhân Mục Môn commune of Khương Đình canton, Thanh Trì district, Thường Tín province in the upper Son Nam region. The village was located in the outskirts southwest of Thăng Long (rising dragon), the dynastic Capital City, on the main road called Thượng Đạo to the city centre over the Tô Lịch River [1]. In 1956, Quan Nhân belonged to Nhân Chính commune of Từ Liêm district. The commune included, at that time, traditional villages of Giáp Nhất, Quan Nhân and Cựu Chính. In 1996, Nhân Chính ward was established from Nhân Chính commune. It is one of the eleven wards of Thanh Xuân district of municipal Hanoi.

Nhân Chính commune is about seven kilometres from the heart of Hanoi and is located in one of the busiest industrial zones with several factories, namely Golden Star Rubber, Thăng Long Tobacco, and Hanoi Washing Powder. In addition, it is not far away from major universities which are situated along the National Motorway Six such as University of Sciences, University of Social Sciences and Humanity, University of Hanoi, University of Architecture, University of Post and Telecommunications, and University of Security. Therefore, the location creates favourable conditions for Nhân Chính in offering good opportunities for jobs, accommodation, and other services. The ward used to have an area of forty hectares of cultivating land out of its total

Manuscript received September 18, 2013; revised November 26, 2013.

Hung Gia Nguyen is with the University of Wollongong, Australia (e-mail: ghn546@uowmail.edu.au). area with two major crops of water rice. However, as the speed of urbanisation has remained very high for the past years, a number of modern residential areas have been constructed to meet the high immigration and population growth. As a result of urbanisation, according to Uncle Thân, the village chief, all the cultivating land of the village has been lost to residential and industrial projects.

The population of the ward, approximately 40,000 people, has grown so fast in recent years because of the urbanisation and immigration. People from rural areas are pouring into the inner city to settle down and find jobs. In 2007, the ward had ninety-five residential groups (tổ dân phố) in sixteen residential areas ( $k h u$ dân cu) [2]. In 2012, the number, which was provided by the chief police officer, increased to a hundred and twelve residential groups in seventeen residential areas. The political and administrative institutions of the ward consist of the Party (Đáng ủy), the People's Council (Hội đồng Nhân dân), the People's Committee (Ủy ban Nhân dân), and several social political organisations from the commune level to residential group level. Those organisations include the Fatherland Front (Mặt trận Tổ quốc), the Women's Union (Hội Phu nũu), Veteran's Union (Hội Cưu chiến binh), Association of Village's Elders (Hội Nguoòi cao tuổi), and Youth Union (Đoàn Thanh niên).

Although Quan Nhân village, today, only exists by name, it has managed to sustain one of the most important characteristics of a village - the members of the community are closely linked by blood relations, religious belief and cultural practice [3]. The once-traditional village has become one of the seventeen residential areas of Nhân Chính ward with a population of about four thousand people divided into thirteen residential groups. Its population is made up from over fifty-five family lineages, of which one group is constituted from the immigrants. Most family lineages have been settling here for hundreds of years and have inter-relationships with one another. However, more and more people are coming to this area to settle down and find jobs. Most people in Quan Nhân are self-employed. They earn their living mainly running small businesses such as stores selling clothes and shoes, grocery, or building materials. Some people work as government officials, school teachers, factory workers, or university lecturers.

As a result of the urbanisation and industrialisation, the village's farming land has all been lost to housing projects, plants, office projects, or shopping complex. The village dwellers have switched from doing traditional agricultural work to starting their own businesses, or working in the public or private sectors. A number of the village dwellers have, with the money they have had from the compensation for the withdrawal of land right use of the farming land, built new houses, bought new furniture for their houses, invested 
in education to look for better jobs, or started a small business. Like other villages of Nhân Chính ward such as Giáp Nhất and Cựu Chính, Quan Nhân has undergone great transformations not only in social and economic, but also in cultural and religious life. The more rapid the immigration is the higher risks of 'cultural corrosion' to traditional community life and of 'cultural alienation' the village is going to confront. Urbanisation and the market economy have not only brought more opportunities for the local people to find better jobs, to access better education, and to obtain higher living standards. Those processes have also created dramatic changes in the lifestyle of the residents. Semi-detached multi-storey houses are replacing the traditional country houses built with bamboo, wood, bricks, and tiles. The people tend to establish nuclear families instead of traditional extended families. However, in spite of the urbanisation and modernity, the communal village-like life has still been sustained and most of the values of village tradition have been passed on to succeeding generations. In Quan Nhân, both urban life and village-like life can be seen, in daily routines and on ceremonial occasions and festivals respectively.

\section{Figures Venerated AND Religious Buildings}

The people in Quan Nhân venerate a figure called Hùng Lãng Công who, according to the inscriptions on the copper tablet enshrined at the sanctuary of the communal hall, was a descendant of the Hùng family of the semi-legendary Hùng dynasty in ancient Vietnam. The village also venerates the hero's wife as its goddess. According to the information from the inscribed script, the copper tablet was made in 1853, the sixth imperial year of Tự Đức of the Nguyễn Dynasty. The script on the copper tablet was a copy of the hagiology written in 1572 by an official of dynastic Ministry of Rites. The hagiology told a story about heroic figure, Hùng Lãng Công, who had led the villagers and his troops to fight against the Nam Chiếu army (Nanzchao) when they invaded Giao Châu ${ }^{1}$ in 863[4]. In a battle when his troop fell in an ambush, he fought to his last breath and heroically died. His wife, on hearing about his husband's death, killed herself to follow him to show her faithfulness and virtue. Being impressed by his heroic deed and wishing to continue to live under his protection, the villagers of Quan Nhân venerated him as their village guardian deity. Like most of other national heroes, he was recognised as village guardian deity and granted Imperial Decrees (Thần sắc) by successive dynastic governments in Medieval Vietnam. However, due to long time, wars, and other conditions, most of the Imperial Decrees have been lost. Only twelve of the Decrees, three of the Lê Dynasty and nine of the Nguyễn Dynasty, have survived until present day. The oldest one was issued in the twenty-sixth imperial year of Cảnh Hưng (1767) and the latest one was issued in the ninth year of the Khải Định (1924).

The people in Quan Nhân worship their village guardian deity at the communal house called dinh. According to the elders in the village, the communal house used to be located

${ }^{1}$ Jiao Zhou, a territory included the present-day north of Vietnam and parts of Guangxi, China. in the middle of a paddy field at the edge of the village. It was moved to the current- location in the middle of Chùa hamlet. The communal house is next to the village pagoda called Sùng phúc tư, part of the village religious complex.

The communal house is the village cultural and religious centre. This house has a design of a Sino-Vietnamese letter of 'Công' (工), one of the most common architecture of communal houses in Vietnam, consisting of the three buildings which are connected to one another: đại dinh (the main hall), chuôi vồ (a building with several other names of lòng máng, thiêu huoong which looks like the handle of a mallet), hậu cung (the sanctuary). There are other buildings which are parts of the complex: nhà hạu thần, the two bays on either side of the sanctuary to honour the village fellows and people of good will who had made great contributions to the building and restoration of the communal house. Inside the communal house, there are a number of boards of parallel words, panels of large characters, and horizontal boards of characters in Sino-Vietnamese. They are valuable archives for studies and research on tradition, literature, and religion. The two bays on either side of the sanctuary accommodate twenty-eight stone posts with inscriptions about individuals and family lineages who had granted donations for the building and restoring of the communal house. The oldest stone post dated back to the twenty-second imperial year of Chính Hòa (1701) of the Lê Dynasty, and the latest one dated back to the eighth year of Bảo Đại (1933) of the Nguyễn Dynasty. The communal house with its additional buildings and the pagoda make a cultural and religious complex for the Quan Nhân village.

Within the precinct of the communal house, Dục Đức Palace is a separated building on the right of the main hall. It is the place where the wife of the village's hero is honoured as Village Goddess. This building faces north and is smaller than the communal house. It is a three-bay brick house with a tiled roof. The floor of the house is paved with flower-patterned tiles on a protruding platform about 20 centimetres from the front yard. The house is enclosed by three doors, with a larger one in the middle. The fringes of the main door look brilliant with ornate engravings of Tú $Q u y ́$ flower blossoms or plants symbolising the four seasons in a year.

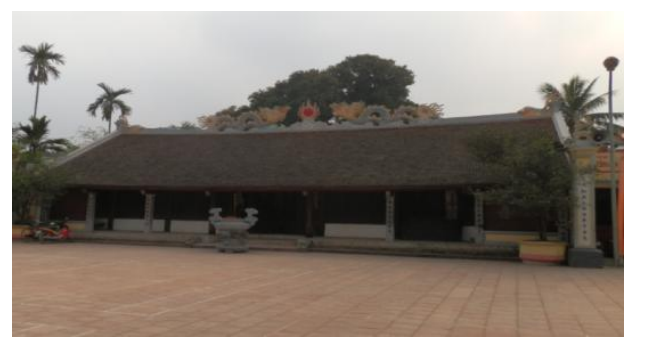

Fig. 1. Traditional village Quan Nhân's communal house was restored and granted certificate of historical and cultural relics by the ministry of culture in 1989. It is the place where the village guardian deity called Hùng Lãng Công is venerated.

Another building which is part of the village's religious complex is Hội xuân shrine, or Đình ngoài (outer communal house). Hội xuân, located on the left hand side of the village gate, is about two hundred metres away from the communal house. The shrine is comprised of a front yard, a main hall, and two supplementary buildings - the left and the right ( $t a \dot{a}$ 


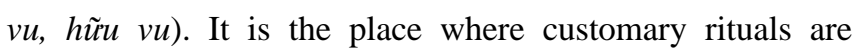
performed to honour the village guardian deity and where the statues of the guardian deity and goddess reside during the village festival. During a mutual festival, the statues of the guardian deities from the four other Mọc villages are to be enshrined at this house before they return to their home shrines. Traditional rites, most of which are related to agricultural cycles, are also performed at this house on particular occasions such as the beginning and the end of summer, of the growing and harvesting seasons, and the New Year, Fig. 1.

\section{ThE RITUALS AND FESTIVAL}

The village rituals of Quan Nhân, like those of other villages, represent the agricultural cycles and are performed according to the lunar calendar which is mainly based on the moon phase rather than the Gregorian calendar. Rituals performed to honour the village guardian are categorised in: customary rituals and major rituals. Customary rituals are performed on the first and the fifteenth of a month, the New Year days, the first and last day of summer, the day of new crop seasons, and so on. On customary ceremonies, offerings to the village guardian deity often include fruits, rice spirit, sticky rice, or a chicken. Offerings may vary according to a particular occasion. Major rituals are performed on days as follows:

- $2^{\text {nd }}$ of August: the death day of the village guardian deity,

- $8^{\text {th }}$ of February: the birth day of the village's goddess,

- From $10^{\text {th }}$ to $12^{\text {th }}$ of February: the village festival,

- $12^{\text {th }}$ of October: the death day of the village's goddess,

Although Quan Nhân is under the administration of the People's Committee of Nhân Chính Commune, the power to settle the village's affairs to a certain extent, as far as religious affairs are concerned, is in the hands of the village's elders in the two organisations: the Association of Village's Elders and the Committee of Village's Historical and Cultural Relics. The Committee of Village's Historical and Cultural Relics (CVHCR), whose members are elected from the elders of the village, is officially subordinate to People's Committee. CVHCR is responsible for running the communal house and rituals to honour the village guardian deity and goddess on behalf of the whole village. CVHCR establishes several bodies to perform the rites at the communal house and at the Dục Đức Palace, to manage the finance and donations, to manage the building and restoration. The Committee is also responsible for organising a meeting with the villagers to nominate two persons who volunteer to work as the custodians ( $c u$ tì) to take care of the communal house and the Palace. CVHCR meets every Thursday to settle the village's affairs. In the past, the village's rituals and institutions 'were partly sustained by communal land'[5]. CVHCR receives financial contributions and donations from the villagers and pilgrims of good will for running the rituals and the village's festival. CVHCR also receives financial support from the People's Committee for the restoration of the communal house complex as it was officially recognised as Historical and Cultural Relic by Ministry of Culture in 1989. Quan Nhân resumed the veneration of village guardian deity and festival in 1989 after a period of suspension due to wars and other reasons. The first mutual festival of the four other Mọc brother villages was organised in 1992 after years of campaigning to seek the participation of the four brother villages and permission from local authorities.

Village festivals are the biggest cultural religious activities in a year. A village festival is usually comprised of the two major groups of activities: lê̂ and họi. Lê̂ are religious rituals to pay homage to the village guardian deities; lêe feature solemnness and sacredness and are performed at the village communal house or shrine. Hộ are characterised with traditional games, drama, and competitions organised to meet the cultural, recreational, and artistic needs of the villagers.

The festival of Quan Nhân village is held for three days from $10^{\text {th }}$ to $12^{\text {th }}$ of February lunar calendar. However, several rites are usually performed two days before the official festival time. The customary festival is held every year; major festivals with solemn rituals and procession are held every two years; festivals with the participation of brother villages are organised every five years. According to the elder villagers, no one knows when Quan Nhân swore brotherhood with four other villages. Since then, the five villages have been called the same name Mọc villages. The five villages consider one another as brothers and every five years they hold a mutual village festival; the five villages take turn to be act as the host village of the festival.

The village festival of Quan Nhân is the biggest cultural and religious event of a year. It is the time that family lineages, pilgrims, the village as a whole to express their gratitude to the deities for the past prosperous year. To run the village festival, a committee of village festival and several bodies are established, and a number of boys and girls serving in the rituals and procession are selected.

\section{Festival Committee}

Days before the village festival, Ban tổ chúc lễ hộ Festival Committee - is established. In the old days, this committee consisted of the village notables, retired dynastic officials, village elders, and scholars. Today, the Festival Committee of Quan Nhân is comprised of twenty or twenty-nine members, based on the nomination and democratic votes at a meeting held with the attendance of members of the Committee of Historical - Cultural Relics, Association of Elders and representatives from family lineages in the village. The Festival Committee consists of several functional bodies such as the Executive, Logistics, Reception, Rites, Security, Finance, Culture, and others. The Committee will dismiss as soon as the festival is closed. The festival usually mobilises the participation of a great number of people in the village. Recalling how big the village festival a year ago was, Uncle Mộc, the head of the Executive Body, said

- "We had twenty-seven functional bodies with over three hundred members and about a hundred and twenty boys and girls serving in the festival."

Most of the members of Festival Committee are heads of functional bodies. The Committee receives support and guidance from peripheral socio-political organisations such as the grass-root party (chi bọ), Association of Women (Hội phu nũ) , Youth Union (Đoàn thanh niên), Association of Veterans (Hội cựu chiến binh), Fatherland Front (Mặt trận Tổ 
quốc), and especially the People's Committee (Ủy ban Nhân dân). The Committee is subordinate to the People's Committee of Nhân Chính Ward, Department of Culture of the People's Committee of Thanh Xuân district.

\section{MRS AND MR KHỞ $\mathrm{CHI}$}

Khơ i chi or Tiên chi used to be one of the top positions of a village's socio-political hierarchy. This position was popular during the Lê dynasty and was sustained until the French colonist administration. Within a village's sphere, there were legislative, executive, and security bodies running the village affairs. About this position, Uncle Thân, Head of Village's Committee of Historical Relics, Head of Association of Village's Elders said

- According to the village regulations (Huoong uoóc) in the old days it says 'purchase the leadership' (Tậu chi). Tậu means 'purchase' and the purchasing of the position had to be done several years ahead before one could officially hold the position. Therefore, one could know which year he or she would be $\mathrm{Mr}$ and Mrs Khởi chỉ of the village festival. And of course he or she had to be selected by the Council of village's elites. It was in the old days but now it is impossible to do that way.

Therefore, in the old days, any individual wishing to become Khơi chì or Tiên chì had to be wealthy enough not only to win in the auction for that position, but also pay for part of the village's expenditure to run the village festival. The purchase of this position was codified in the village's regulations. Once one became Tiên chì he was the village chief and representative. He would cooperate with the commune chairman ( $x \tilde{a}$ truoong), who was elected and officially recognised by the central court, to settle all the village's administrative affairs. Today, Khơ $i$ chi is the symbolic chief of a village. Khơ i chi may be a male or female elder depending whether a village venerates a male or female guardian spirit.

The selection of Khơi chi demonstrates that Quan Nhân has sustained its tradition which pays respect to seniority and social hierarchy, especially through the lenses of worshiping guardian deities that has been reinvented in recent years. $\mathrm{Mr}$ and Mrs Khơ $i$ chỉ will take the responsibilities of training the girl and boy assistants in their certain roles while they serve the village festival and rituals. The training and rehearsal may take months before the festival. According to Quan Nhân's regulations, anyone native to the village, regardless of male or female, has only one opportunity in their lives to hold that position. Their names will be written in the village record book for next generations' reference.

\section{MR AND MRS TổNG $C \grave{o}$}

During the village festival of Quan Nhân, Mrs and $\mathrm{Mr}$ Tổng $c \dot{o}$ are people whose responsibility is to manage the chess games. Like Mrs and Mr Khởi chỉ, Tổng cò should be wealthy village fellows who can sponsor their own teams when necessary. The way to select the positions of Tổng $c \dot{o}$ is approximately the same way to select Khơ $i$ chi. Once having accepted their positions, Mrs and Mr Tổng cò will have to train their own girl or boy assistant in their roles as chess pieces. The Festival Committee will provide the chess teams with appropriate clothing for each role. It is very honourable to be selected for the position of Mrs or Mr Tổng cờ of the village festival.

\section{BOY AND GIRL ASSISTANTS}

Village festival requires the participation of a number of boys and girls serving in the rituals and recreational activities. The boys and girls who serve the festival are called giai. According to uncle Thân, giai should be 'unmarried' and aged from fourteen to eighteen. That is the first criterion. The second, the boys and girls selected should be ones who behave well in the community and come from families with good background. For Chinese chess, giai are younger than the ones serving in the rituals, from fifteen to seventeen years old. The number of boys and girls will be recruited depends on the demand which varies from year to year. The number can be multiplied by three, four, or five depending on the distance that the procession will go. For example, the number of boys for the carrying of the eight-carrier palanquin (bát cống) for the guardian deity should be multiplied by three and that equals twenty-four. And the boys will take turn to shoulder the palanquin. Therefore, the number of boys and girls selected will be made by the executive body of the Festival Committee. The boys and girls serving in the festival are divided into the following groups:

- giai kiệ: boys and girls whose responsibility is to carry the chairs of the goddess and the guardian deity. The boys wear sleeveless red jackets decorated with yellow fringes, yellow belts, black turbans, white shirts and white trousers underneath. The girls are dressed in red robes with yellow green tassels falling from the waist, black pants, and black turbans.

- Lọ bộ: boys and girls who carry the ritual objects and the flags. The boys wear blue robes and blue turbans. The girls wear light pink robes with pink turbans, white pants and white shoes.

- Giai cò: boys and girls who act as chess pieces in games of cò̀ ngườ (human chess)

The preparation for the festival not only mobilizes the whole community's resources, especially the increasing participation of village dwellers of various age groups, but also requires good cooperation among the village members and between self-managing organisations of the village with the local authority or in this case, the board of village festival with the People's committee of Nhân Chính ward and Thanh Xuân district and other political social organisations in consistent with the laws and regulations. Moreover, the village festival helps to create environment for the cooperation and harmony of various religious forms with a village. The village festival needs elaborately planned by the Festival Committee based on the village's regulations and experience.

The festival of Quan Nhân Village consists of several rites like those of other traditional village festivals. The festival commences with a rite called lễ mở cưa dìn (opening the communal house) performed on the $10^{\text {th }}$ and ends with $l \tilde{e} t a$ (thanksgiving) performed on the $12^{\text {th }}$. The 2011 festival of Quan Nhân was organised as follows. 


\section{THE RITE OF WATER AND PURIFICATION}

This is a very important rite in agrarian culture as old saying states how import water is to rice cultivation 'Water the first, fertilizer the second, industriousness the third, and seeds the fourth'. In the past, according to Uncle Hồng, the communal house custodian, a solemn water procession was performed on the 8th of February, two days before the festival. Water was taken to the communal house from the village well which is located by the pond between Quan Nhân and Cự Chính village. However, as the well had been polluted, this rite was not performed for many years. In recent years, the rite has been revived and rainwater is used to replace water which used to be fetched from the village well or a nearby river. About the rite of water, uncle Thân said

- "The water for the purification used to be fetched from the village well within the spring house's precinct. It has drained out and been much polluted. Now the water for purification is from rainwater."

Purification is a rite to wash the deity statue, tidy the altar, and other ritual objects to make sure that everything is clean before the village festival. Purification is done with great care and respect to the guardian deity. For Quan Nhân, the people who are selected to perform this rite should first 'purify' themselves by having a careful wash and wearing masks and gloves during the purification process. Even days before rite, all participants should eat vegetarian food; they should restrain themselves from misbehaving in the community and from having sexual intercourse. Quan Nhân's rite of purification is performed at an eight-roofed pavilion called nhà Mộc dục (House of Purification) and only nominated members can enter the house while the purification is in progress.

\section{INCENSE OFFERING}

On the $9^{\text {th }}$ of February, members of Board of festival and functional bodies gather at the communal house to present themselves to the guardian deity and report to him about the coming village festival. Then the body of rites instruct volunteers to display the wooden elephant, the horses, the two palanquins Long đình (dragon chair) and Kiẹu bát cống (chair shouldered by eight persons) and other ritual objects on the front yard. The Cò̀ thần (guardian flag) and national flag are arisen on high poles in front of the gate of the communal house. Festival flags are hung along the village path from the communal house to the Hội xuân shrine. A meeting with the attendance of members of the Board of Historical Relics, Village Association of Elders and Board of Village Festival is held in the afternoon after the presentation. The Board of Festival sends a team of dragon dancers with drum and gongs to the houses of Mrs and Mr Khơ i chi, Mrs and Mr Tông cò (Chess manager) to accompany them to the meeting at the communal house. At this meeting, on behalf of the Board of Village Festival, the chairman will formally introduce Mrs and Mr Khơ i chi and Mrs and Mr Tống cò̀ with their duty and deliver them bundles of flowers as symbols to pay them honour to the village. Their names will be written on the village record book to honour them at present and in the future.

On the $10^{\text {th }}$, a big sacrificing ceremony was performed, representatives from fifty-two family lineages living in the village, as having been registered with the Board of village festival, proceeded to the main hall with offerings delivering to the guardian deity. After the offering, the Board double-checked every step of preparation to make sure everything is ready for the village coming into their yearly festival.

\section{The Solemn Rituals}

The $11^{\text {th }}$ of February, in early morning, representatives of the executive body came to the houses of Mrs and Mr Khơ $i$ chi, Mrs and Mr Tống cò to accompany them to the communal house. All the boys and girls would be summoned for the coming solemn procession. Mr Khơ i chi with his boys and Mrs Khơ i chi with her girls queuing in two lines proceeded to the front yard of the communal house. First a group of ritual men with their assisting boys in formal ritual clothes of blue robes, arising-pointed shoes, and ritual caps came to queue in front of the altar in the middle compartment of the main hall. They would kowtow in front of the altar according to the callings of right and left announcers (đông xuoóng, tây xương). At the same time, the same process was being conducted by the ritual women and her girls who were in red robes, red turbans, and white shoes in front of the altar of the village goddess in Duc dúc palace.

Next, the female and male custodians with the help of several girls and boys came to move the incense burner for the goddess and the guardian deity respectively to the chairs called Long dinh and the statues of the goddess and the guardian deity to bigger chair called Bát cống (meaning shouldered by eight people). While doing that, the custodians had to wear masks and gloves to make sure not to offend the goddess and the guardian deity. The chief ritual man in red robe and red hat with his team accompanies the statue in beautiful gongs and drum songs. In the same way, the chief ritual woman with her team in red robes and red turbans accompanies the goddess statue to her Bát cống. Members of the executive body would guide other teams to stand in their position to get ready for the procession of the guardian deity and the goddess to the Hội Xuân shrine.

The chairman on behalf of Board of village festival delivered a speech to express thanks to the People's Committee of Nhân Chính ward, other socio-political organisations within the ward, and all the village fellows for their support and formally to open the village festival.

\section{THE PROCESSION}

The procession was elaborately organised in fourteen groups in hour of the Deity and eight groups of Goddess. The order and the route of the procession were carefully planned by the Festival Committee. The statues of the Deity and the Goddess, worshipping objects, flags, and horses were carried to the Hội Xuân shrine and back to the communal house and Dục Đức Palace in the afternoon. Leading the procession, the boys wore dragon and lion puppets dancing in tune with the drums and gongs. The horse and elephant group came right after the dragon dancing group. Next were the Buddhist representatives. They carried the Buddhist flags, the festival flags and national flags. The elder women were dressed in brown robes. The colour means simple and pure, free from every day joys and sorrows. The bồng dancers came right after that; they were a group of small boys and girls, aged from eight to twelve standing in two lines, dancing and 
playing rice drums ${ }^{2}$. A number of villages in the Red River delta perform this kind of dance during their village festival. The palanquins of the Deity were carrying eight boys who are dressed in red jackets and wear black turbans. The groups carrying the flags and worshipping objects were following. A group of ritual officials followed the flags. Each of members of this group should master the rites at the communal house. They were wearing green robes with long sleeves, green cap, and up-turned nose shoes. Apart from kowtowing and praying to the guardian deity at the festival, they perform their job on all ceremonial days all year round. At the end of the procession were village fellows and pilgrims.

\section{RECREATIONAL ACTIVITIES}

During the village festival, a number of recreational activities were organised in combination with the kowtowing, sacrifice offering, and procession. Recreational activities are very much similar from village to village. However, particular activities may be performed differently. Like other villages, the village of Quan Nhân came into village festival with various recreational activities such as rooster fights, Chinese chess, and traditional drama chèo - a form of musical theatre with dance traditionally performed by peasants. What makes the recreational activities of the festival of Quan Nhân is a special chess game called $C \grave{o}$. người.

Chess games are very popular recreational activities during traditional festivals. A game of chess symbolises a battle between two sides - black and white. Each side has sixteen pieces - five pawns, two elephants, two cannons, two chariots, two ministers, two horses, and one general. Therefore, there are thirty- two pieces altogether on a chess board. The normal chess game is played on a board with the pieces made of wood, plastic, or ivory. During village festivals, apart from the normal chess, there are special chess games called Cờ người. On a game of Cờ người, the pieces are human beings, usually boys and girls.

Cò ngườ requires very careful preparation which usually takes months. The first thing to do is to recruit boys and girls to act as the pieces. It requires the participation of sixteen boys and sixteen girls. The boys and girls serving as the pieces in the chess games should be good boys and girls coming from respected families. The second is to select two generals, one boy and one girl among the sixteen boys and sixteen girls. According to Uncle Hồng, the communal house custodian, to recruit the boys and girls, Quan Nhân village calls for volunteers and nominations from family lineages. The last stage of the preparation, which often lasts for weeks, is training the boys and girls to act in the roles of the pieces.

While acting on the board, each participant holds a banner with large characters on it showing whether he or she is acting as a pawn, an elephant, a canon, or a minister. Each actor has a chair to sit on and is shaded under an umbrella in case of a sunny or rainy weather. The generals look different from the others in styles of clothes and colour. Each of them has both a chair and a bigger umbrella held by a boy or a girl behind her. The boy actors represent the black side. They are dressed in red vest with yellow fringes, black turbans, and

\footnotetext{
${ }^{2}$ Com drums are traditional musical instruments. A com drum has a cylindered wooden frame with two tops made of tanned buffalo leather. When playing the drum, players apply a handful of rice on the two tops. The drums make beautiful harmonic sounds.
}

white trousers. The girl actors represent the white side. They are dressed in yellow vests with red fringes, blue turbans, and white trousers. Each side has its own Chess manager and an assistant for the manager. When the mock battle begins, the boys and girls move their positions according to the order of the players. The game ends when either of the generals is checkmated. The Chess managers and their assistants are to observe rule of the game. Có̀ ngườ of Quan Nhân village is often held on the $10^{\text {th }}$, one day before the procession. A game of chess often attracts much attention from village fellows and pilgrims.

The recreational activities during Quan Nhân village festival established a revival of agrarian daily routines, or in other word reinvented a tradition and a historical event which was the pride of the village and utilised this tradition as a lesson for their children, grandchildren, great grandchildren about patriotism, about training oneself to be ready to protect the homeland and the country.

Despite a number of drawbacks of the worship of village guardian deities and village festival which have challenged the administration of cultural activities of the local authorities, the residents of Quan Nhân 'felt a need to revive their tradition' [6]. The elders of Quan Nhân wish to transmit their memory of the festival and their gratitude for the protection of the guardian deity to younger generations. To sustain the tradition in the condition of urbanisation and the market economy, on one hand, the rival of the worship of village guardian and festival should be consistent with the policies in cultural activities of the Party-State of Vietnam and the regulations of the local authorities. On the other hand, the people in Quan Nhân are doing their best to take the most advantages of the values which modernity can accommodate and reject the disadvantages.

\section{REFERENCES}

[1] D. T. The and P. T. Thoa, "The Designations of Communes and Villages in Vietnam in 19th century (from Nghệ An province northwards)," Hanoi: Khoa học - Xã hội, 1981, pp. 47.

[2] P. M. Phương, "Vietnam-Cultural Regions: the festival of the five Mọc villages in Hanoi in 2010," Hanoi: Văn hóa Thông tin, pp. 19.

[3] P. H. Lê, "Research on the Vietnamese village," in Vietnam: Borderless Histories, T. T. Nhung and A. Reid, Eds. Wisconsin: The University of Wisconsin Press, 2006, pp. 28.

[4] N. S. Liên, The Complete Annals of the Great Viet, Hanoi: Thời Đại, 2011, pp.111.

[5] H. V. Lương, Revolution in the Village: Tradition and Transformation in North Vietnam, 1925-1998, Honolulu: University of Hawaii Press, 1992, pp. 56.

[6] N. V. Huy, N. A. Ngoc, and N. T. Dung, "The village god's journey," in Vietnam: Journeys of Body, Mind, and Spirit, N. V. Huy and L. Kendall, Eds. California: University of California Press, 2003, pp. 222.

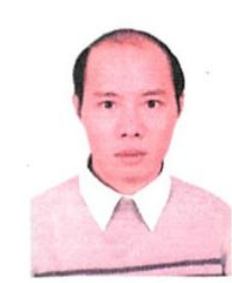

Hung Gia Nguyen was born in Bắc Ninh province, Viêtnam, he was born on September 11, 1973. He received bachelor in English, Hanoi University for Teachers of Foreign Languages, Hanoi, Vietnam, 1995, bachelor in Political Studies, National Academy of Politics and Administration, Hanoi, Vietnam, 2003; Master in Religious Studies, National Academy of Politics and Administration, Hanoi, Vietnam, 2006; Certificate in Leadership and Administration, National University of Australia, Canberra, Australia, 2009. Currently, he has been Ph.D. student in Philosophy and Religions at the Faculty of Law, Humanities, and the Arts of University of Wollongong in Australia. 